\title{
Toxicity of neem oil to the cassava green mite Mononychellus tanajoa (Bondar) (Acari: Tetranychidae)
}

\author{
Amanda C.B. Silva ${ }^{1}$, Adenir V. Teodoro ${ }^{2 *}$, Eugênio E. Oliveira ${ }^{3}$, Adriano S. Rêgo ${ }^{1}$, and Rafael R. Silva ${ }^{1}$
}

\begin{abstract}
Neem (Azadirachta indica A. Juss.)-derived pesticides have been used against a wide range of agricultural pests including tetranychid mites. Approaches combining lethal and sublethal toxicity studies of neem pesticides towards tetranychid mites are necessary to a comprehensive evaluation of such products. Here, we evaluated the lethal and sublethal toxicity of the neem oil Bioneem to the cassava green mite Mononychellus tanajoa (Bondar) by integrating lethal concentration (LC) with population growth and biological parameter studies. According to Probit analyses the concentration of neem oil Bioneem which kills $50 \%$ of the population $\left(\mathrm{LC}_{50}\right.$ ) of $M$. tanajoa was $3.28 \mu \mathrm{L} \mathrm{cm}^{-2}$, which is roughly twice the field concentration recommended of this biopesticide to control pest mites $\left(1.7 \mu \mathrm{L} \mathrm{cm}^{-2}\right)$. The growth rate of the cassava green mite steadily decreased with dosages of neem oil. Furthermore, sublethal concentrations of the neem oil corresponding to the $\mathrm{LC}_{50}$ reduced the periods of the immature stages of $M$. tanajoa resulting in a shorter developmental time. Similarly, the number of eggs per day and the number of eggs per female per day, a proxy for fecundity, were drastically reduced in $M$. tanajoa females exposed to the $\mathrm{LC}_{50}$ of neem oil. Based on our comprehensive approach we conclude that the neem oil showed lethal as well as sublethal toxicity on growth rate and biological parameters such as duration of immature stages and fecundity of the cassava green mite M. tanajoa and it could be used as an ecological alternative for the management of this pest.
\end{abstract}

Key words: Azadirachta indica, biological studies, botanical pesticides, growth rate, sublethal effects.

\section{INTRODUCTION}

Cassava Manihot esculenta Crantz (Euphorbiaceae) is considered a key cash crop and staple food source for smallholders in many tropical and subtropical regions (Suja et al., 2010). The cassava green mite Mononychellus tanajoa (Bondar) (Acari: Tetranychidae) is regarded as a serious pest of cassava fields in Northeastern Brazil and in other tropical countries (Moraes and Flechtmann, 2008; Rêgo et al., 2012). Cassava green mite damage may include reduction of photosynthetic rate, deformation and death of shoots, leaf dropping, yield losses and plant death (Moraes and Flechtmann, 2008). Although there are predatory mites associated with the cassava green mite in the field, outbreaks of this pest usually occur annually during the dry season of the year (Onzo et al., 2005;

\footnotetext{
${ }^{1}$ Universidade Estadual do Maranhão, Programa de Pós-Graduação em Agroecologia, 65054-970, São Luís, Maranhão, Brasil.

${ }^{2}$ Embrapa Tabuleiros Costeiros, Av. Beira Mar 3250, 49025-040, Jardins, Aracaju, Sergipe, Brasil.

*Corresponding author (adenir.teodoro@embrapa.br).

${ }^{3}$ Universidade Federal de Viçosa, Departamento de Biologia Animal, Entomologia, 36570-000, Viçosa, Minas Gerais, Brasil.

Received: 25 March 2013.

Accepted: 25 July 2013.

doi: $10.4067 /$ S0718-58392013000300016
}

Moraes and Flechtmann, 2008; Rêgo et al., 2012; 2013).

Botanical pesticides based on neem (Azadirachta indica A. Juss.) efficiently control a wide range of agricultural pests including tetranychid mites (Gonçalves et al., 2001; Mordue (Luntz) et al., 2005; Venzon et al., 2005; Gauraha and Singh, 2011). Although azadirachtin is the most biologically active compound, neem seed extract also contains deacetylnimbin, deacetylsalannin, nimbin, and salanin (Stark and Walter, 1995; Caboni et al., 2006). In addition to being toxic to pests, these active chemical neem compounds have also been emphasized by their low toxicity to mammals, short field persistence and relative selectivity to natural enemies (Caboni et al., 2006; Isman, 2006; Khater, 2012).

The mean lethal concentration $\left(\mathrm{LC}_{50}\right)$ is broadly used as a parameter for evaluating and comparing toxicity of a pesticide to arthropods (Desneux et al., 2007; Ullah et al., 2011); however, it does not consider sublethal effects of this concentration. Non-lethal concentrations of pesticides affects physiology and behavior of arthropods causing, for instance, reduction of fertility, foraging interference, repellence, feeding deterrence, changes in biological parameters, morphological abnormalities, interferences in foraging behavior, and reduced growth rate (Teodoro et al., 2005; Kim et al., 2006; Marcic, 2007; Desneux et al., 2007; Teodoro et al., 2009; Cordeiro et al., 2010). 
Population growth toxicity studies provide valuable insights on the effects of pesticides on a given species (Stark and Banks, 2003; Martínez-Villar et al., 2005). The instantaneous rate of increase $\left(r_{i}\right)$, which is closely correlated with the intrinsic growth rate $\left(\mathrm{r}_{\mathrm{m}}\right)$, is a measure o population increase over a given period of time and it has been successfully used to estimate population growth of arthropods (Stark and Rangus, 1994; Teodoro et al., 2005). In the specific case of sublethal effects of pesticides on the biology of pest mites, changes in longevity, fertility, survival, duration of developmental phases have been reported (Gonçalves et al., 2001; Marcic, 2007; Alzoubi and Cobanoglu, 2008). Studies focusing on the sublethal toxicity of botanical pesticides like neem oil on growth rate and biological parameters of phytophagous mites are needed to fully assess the effects of these pesticides to such pests.

Here, we aimed to evaluate both lethal and sublethal toxicity of a neem-based pesticide to the cassava green mite $M$. tanajoa by integrating lethal concentration estimates with demographic and biological studies.

\section{MATERIALS AND METHODS}

\section{Mite rearing}

Mononychellus tanajoa colonies were established from mites collected from a cassava plot maintained without pesticide applications in São Luís $\left(02^{\circ} 31^{\prime} 48^{\prime \prime} \mathrm{S}\right.$, 4418'10" W), Maranhão state, Brazil. Potted cassava plants cv. Amarela BR 1667 containing mite colonies were maintained in a greenhouse at uncontrolled conditions. Overexploited plants were replaced by new ones and no pesticides were applied. All bioassays were conducted at $27 \pm 10{ }^{\circ} \mathrm{C}, 60 \pm 20 \%$ relative humidity, and a $10: 14 \mathrm{~h}$ photoperiod.

\section{Concentration-mortality bioassays}

Concentration-mortality bioassays were carried out to estimate the lethal concentrations of the neem oil Bioneem (Bioneem, Araçuaí, Minas Gerais, Brazil) to adult females of $M$. tanajoa at the beginning of their reproductive period (ca. $10 \mathrm{~d}$ old). A preliminary test was conducted in order to determine a wide concentration range where the highest concentration unable to kill $M$. tanajoa and the smallest concentration able to kill $100 \%$ of $M$.tanajoa were determined. Afterwards, six concentrations within this range were used to estimate the lethal concentration values (LCs). The neem oil was sprayed through a Potter tower (Burkard, Rickmansworth, UK) in cassava leaf discs (3.5 cm diameter) at $0.34 \mathrm{bar}(34 \mathrm{kPa})$ pressure with a $2.3 \mathrm{~mL}$ spray aliquot. Control leaf discs were sprayed with distilled water.

Sprayed cassava leaf discs were allowed to dry for $1 \mathrm{~h}$ before being placed in a Petri dish $(10 \mathrm{~cm}$ diameter $\times 1.5$ $\mathrm{cm}$ depth) filled with distilled water. Each leaf disc was centrally perforated by a pin attached to the bottom of the
Petri dish. Subsequently 10 adult females of $M$. tanajoa were placed on each leaf disc. Six replicates (leaf discs) for each concentration were used. Mite mortality was assessed after $72 \mathrm{~h}$ exposure and concentration-mortality curves were estimated by Probit analysis using PROC PROBIT procedure (SAS Institute, 2002). The likelihood ratio chi-square $\left(x^{2}\right)$ goodness-of-fit was applied to evaluate whether the data adequately conformed to PROBIT model (Robertson et al., 2007).

\section{Growth rate bioassays}

The instantaneous rate of increase $\left(\mathrm{r}_{\mathrm{i}}\right.$ ) was used to evaluate the sublethal effects of the neem oil to M.tanajoa based on reproduction and mortality data. This index is calculated using the equation $r_{i}=\left[\ln \left(N_{f} / N_{0}\right)\right] / t$, where $N_{f}$ is the final number of live mites (including eggs and immatures), $\mathrm{N}_{0}$ is the initial number of mites, and $\mathrm{t}$ is the time interval ( 7 d) elapsed between onset and end of the bioassay (Walthall and Stark, 1997). Positive $r_{i}$ values indicate population growth, $r_{i}=0$ indicate a stable population, and negative $r_{i}$ values represent population decline and heading towards extinction (Walthall and Stark, 1997).

Five adult females of $M$. tanajoa as previously described were placed on arenas sprayed with different lethal concentrations ( $\left.\mathrm{LC}_{5}, \mathrm{LC}_{10}, \mathrm{LC}_{25}, \mathrm{LC}_{50}, \mathrm{LC}_{95}, \mathrm{LC}_{99}\right)$ of neem oil, which were based on the concentrationmortality curves previously obtained. This allowed us to evaluate the effects of increasing LCs on the growth rate of $M$. tanajoa. Control arenas $\left(\mathrm{LC}_{0}\right)$ were sprayed only with distilled water. Five replicates for each concentration were used. A male was added to each arena and replaced whenever it died. Regression analysis was conducted to assess the effects of increasing LC of neem oil on the $\mathrm{r}_{\mathrm{i}}$ of $M$. tanajoa using Sigma Plot (Systat Software Inc., 2008).

\section{Biological parameters studies}

The sublethal toxicity of the neem oil was further evaluated by comparing some biological parameters of the cassava green mite $M$. tanajoa exposed to either the $\mathrm{LC}_{50}$ or the $\mathrm{LC}_{0}$ (control) of the neem oil. $\mathrm{LC}_{50}$ was chosen for being commonly used as a parameter for evaluating and comparing the toxicity of a pesticide to arthropods. Ten mated females of $M$. tanajoa were confined to cassava leaf discs for $4 \mathrm{~h}$ to obtain eggs of similar age. Leaf discs $(3.5 \mathrm{~cm}$ diameter) were sprayed through a Potter tower with either the $\mathrm{LC}_{50}$ of neem oil $\left(3.28 \mu \mathrm{L}\right.$ neem oil $\left.\mathrm{cm}^{-2}\right)$ or distilled water $\left(\mathrm{LC}_{0}\right.$, control) at the same conditions described above. Eggs were individually transferred to leaf discs and observed twice a day (08:00 and 16:00 h) until reaching adulthood. Newly molted females and males were observed once a day (08:00 h) until their death. One male of the stock culture was added to each leaf disc containing a newly molted female and the periods of preoviposition, oviposition, postoviposition, number of eggs per female, and number of eggs per female per day were 
recorded. The biological parameters periods of immature development, egg-to-adult, preoviposition, oviposition, postoviposition, eggs per female, and eggs per female per day of the cassava green mite $M$. tanajoa exposed to the $\mathrm{LC}_{50}$ of neem oil and the control $\left(\mathrm{LC}_{0}\right)$ were compared by $\mathrm{t}$ tests using the software Statistica 7.0 (StatSoft Inc., 1984-2004). Periods of egg, larva, protochrysalid, protonymph, deutochrysalid, deutonymph, teliochrysalid, preoviposition, and postoviposition were log-transformed prior analyses as they violated assumptions of a normal distribution. Untransformed means \pm standard deviation are shown.

\section{RESULTS}

Table 1 shows the lethal concentrations $\left(\mathrm{LC}_{5}, \mathrm{LC}_{10}\right.$, $\mathrm{LC}_{25}, \mathrm{LC}_{50}, \mathrm{LC}_{95}, \mathrm{LC}_{99}$ ) of neem oil that were estimated by concentration-mortality bioassays. The concentration recommended for field applications of the neem oil Bioneem according to the biopesticide label $(15 \mathrm{~mL}$ neem oil $\mathrm{L}^{-1}$ distilled water or $1.7 \mu \mathrm{L}$ neem oil $\mathrm{cm}^{-2}$ ) matched the $\mathrm{LC}_{30}$ according to Probit analysis (data not shown).

The instantaneous rate of increase $\left(\mathrm{r}_{\mathrm{i}}\right)$ of $M$. tanajoa linearly decreased with increasing lethal concentrations of neem oil (Figure 1). Positive values of $r_{i}$ indicate population growth of $M$. tanajoa exposed up to the $\mathrm{LC}_{50}$, i.e., $3.28 \mu \mathrm{L}$ neem oil $\mathrm{cm}^{-2}\left(\mathrm{r}_{\mathrm{i}}=0.40\right.$ $\left.\pm 0.05 \mathrm{~d}^{-1}\right)$. Mite populations exposed to $\mathrm{LC}_{95}(25.27$ $\left.\mu \mathrm{L} \mathrm{cm}^{-2}\right)$ and $\mathrm{LC}_{99}\left(58.87 \mu \mathrm{L} \mathrm{cm}^{-2}\right)$ of neem oil were

Table 1. Toxicity of the neem oil Bioneem to the cassava green mite Mononychellus tanajoa $\left(n=360, x^{2}=12.78\right.$, degrees of freedom $=4, p=$ 0.81). $\mathbf{L C}=$ lethal concentration; $\mathrm{CI}=$ confidence interval.

\begin{tabular}{ccccccc}
\hline Slope $\pm \mathrm{SE}$ & $\begin{array}{c}\mathrm{LC}_{5} \\
(95 \% \mathrm{CI})\end{array}$ & $\begin{array}{c}\mathrm{LC}_{10} \\
(95 \% \mathrm{CI})\end{array}$ & $\begin{array}{c}\mathrm{LC}_{25} \\
(95 \% \mathrm{CI})\end{array}$ & $\begin{array}{c}\mathrm{LC}_{50} \\
(95 \% \mathrm{CI})\end{array}$ & $\begin{array}{c}\mathrm{LC}_{95} \\
(95 \% \mathrm{CI})\end{array}$ & $\begin{array}{c}\mathrm{LC}_{99} \\
(95 \% \mathrm{CI})\end{array}$ \\
\hline $1.46 \pm 0.16$ & $0.4^{1}$ & 0.7 & 1.4 & 3.28 & 25.3 & 58.9 \\
$(0.2-0.6)$ & $(0.4-0.9)$ & $(1.0-1.8)$ & $(2.6-4.0)$ & $(17.3-43.3)$ & $(35.6-123.1)$
\end{tabular}

${ }^{1} \mu \mathrm{L}$ neem oil $\mathrm{cm}^{-2}$.

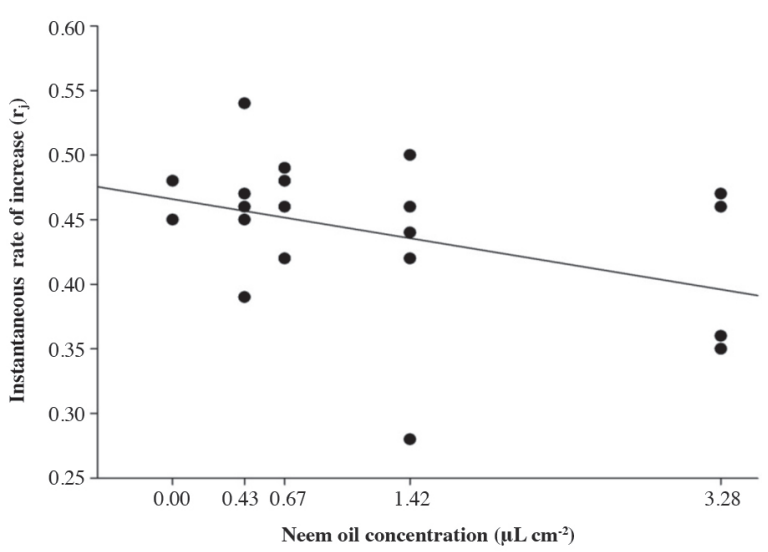

Figure 1. Instantaneous rate of increase $\left(r_{i}\right)$ of the cassava green mite Mononychellus tanajoa exposed to increasing lethal concentrations of the neem oil Bioneem $\left(y=0.4666-0.0213 x ; F_{1,23}=5.84 ; p=0.024, R^{2}\right.$ $=0.20) . \mathrm{LC}_{50}: 3.28 \mu \mathrm{L}$ neem oil $\mathrm{cm}^{-2}$. extinct within $7 \mathrm{~d}\left(\mathrm{~N}_{\mathrm{f}}=0\right)$.

Eggs of the cassava green mite $M$. tanajoa exposed to the $\mathrm{LC}_{50}(3.88 \pm 0.74 \mathrm{~d}, \mathrm{n}=129)$ of neem oil hatched faster than those unexposed $(4.76 \pm 0.30 \mathrm{~d}, \mathrm{n}=407)(d f=$ $534, t=20.24, p<0.001$ ) (Figure 2). Likewise, the larval period of $M$. tanajoa exposed to $\mathrm{LC}_{50}$ of neem oil was reduced $(0.66 \pm 0.46 \mathrm{~d}, \mathrm{n}=95)$ compared with the control $(1.03 \pm 0.27 \mathrm{~d}, \mathrm{n}=101)(d f=194, t=9.09, p<0.0001)$ (Figure 2). $\mathrm{LC}_{50}$-exposed mites had also shorter periods of protochrysalid $\left(\mathrm{LC}_{50}: 0.60 \pm 0.27 \mathrm{~d}, \mathrm{n}=66 ; \mathrm{LC}_{0}: 0.85 \pm\right.$ $0.22 \mathrm{~d}, \mathrm{n}=83 ; d f=147, t=7.51, p<0.0001)$, protonymph $\left(\mathrm{LC}_{50}: 0.75 \pm 0.49 \mathrm{~d}, \mathrm{n}=63 ; \mathrm{LC}_{0}: 0.96 \pm 0.24 \mathrm{~d}, \mathrm{n}=77\right.$; $d f=138, t=5.42, p<0.0001)$, deutochrysalid $\left(\mathrm{LC}_{50}: 0.53\right.$ $\pm 0.23 \mathrm{~d}, \mathrm{n}=49 ; \mathrm{LC}_{0}: 0.75 \pm 0.16 \mathrm{~d}, \mathrm{n}=73 ; d f=120, t=$ $7.39, p<0.0001)$, deutonymph ( $\mathrm{LC}_{50}: 0.70 \pm 0.50$ days, $\mathrm{n}=39 ; \mathrm{LC}_{0}: 1.00 \pm 0.19 \mathrm{~d}, \mathrm{n}=70 ; d f=107, t=6.65, p<$ $0.0001)$, and teliochrysalid $\left(\mathrm{LC}_{50}: 0.51 \pm 0.22 \mathrm{~d}, \mathrm{n}=29\right.$; $\left.\mathrm{LC}_{0}: 0.99 \pm 0.20 \mathrm{~d}, \mathrm{n}=67 ; d f=94, t=11.82, p<0.0001\right)$ (Figure 2).

Mites exposed to the sublethal concentration of neem oil reached adulthood earlier $\left(\mathrm{LC}_{50}: 9.64 \pm 1.01\right.$ $\mathrm{d}, \mathrm{n}=23 ; \mathrm{LC}_{0}: 10.31 \pm 0.77 \mathrm{~d}, \mathrm{n}=67 ; d f=88, t=3.29$, $p=0.001)$ and had shorter oviposition $\left(\mathrm{LC}_{50}: 10.05\right.$ $\pm 5.84 \mathrm{~d}, \mathrm{n}=22 ; \mathrm{LC}_{0}: 16.31 \pm 1.32 \mathrm{~d}, \mathrm{n}=22 ; d f=$ $42, t=4.90, p<0.0001)$ and postoviposition $\left(\mathrm{LC}_{50}\right.$ : $1.33 \pm 0.81 \mathrm{~d}, \mathrm{n}=06 ; \mathrm{LC}_{0}: 2.59 \pm 0.73 \mathrm{~d}, \mathrm{n}=22 ; d f$ $=26, t=5.13, p<0.0001)$ periods than control mites. However, the duration of the period of preoviposition of $M$. tanajoa was not affected by the neem oil $\left(\mathrm{LC}_{50}\right.$ : $1.60 \pm 0.98 \mathrm{~d}, \mathrm{n}=15 ; \mathrm{LC}_{0}: 1.28 \pm 0.37 \mathrm{~d}, \mathrm{n}=56 ; d f=$ $69, t=-1.22, p=0.22)$. Females of $M$.tanajoa exposed to $\mathrm{LC}_{50}$ of neem oil had reduced total $\left(\mathrm{LC}_{50}: 15.43 \pm\right.$ 10.59 eggs per female, $\mathrm{n}=16 ; \mathrm{LC}_{0}: 84.45 \pm 19.79 \mathrm{eggs}$ per female, $\mathrm{n}=22 ; d f=36, t=12.65, p<0.0001)$ and daily $\left(\mathrm{LC}_{50}: 1.17 \pm 0.46\right.$ eggs per female per day, $\mathrm{n}=$ 16 ; $\mathrm{LC}_{0}: 5.17 \pm 1.01$ eggs per female per day, $\mathrm{n}=22$; $d f=36, t=14.60, p<0.0001)$ fecundity.

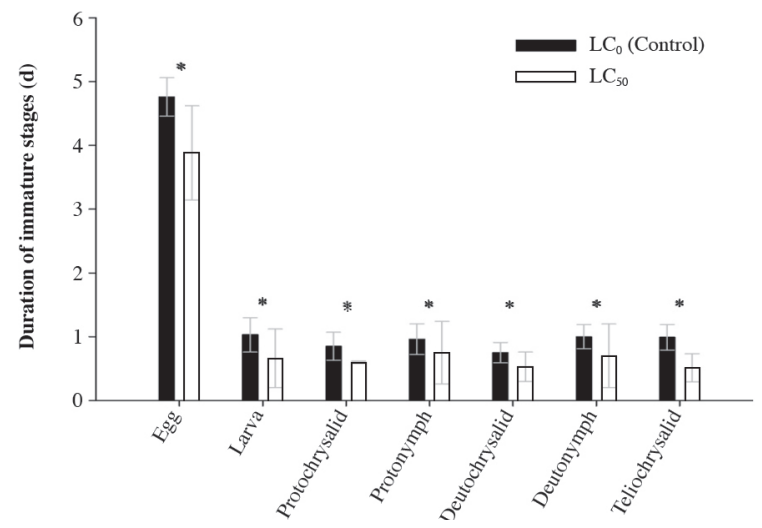

Figure 2. Durations of immature stages of the cassava green mite Mononychellus tanajoa exposed to $\mathrm{LC}_{50}\left(3.28 \mu \mathrm{L} \mathrm{cm} \mathbf{c m}^{-2}\right)$ and $\mathrm{LC}_{0}$ (control) of the neem oil Bioneem. Means \pm SD are given. Asterisks above bars denote significant differences within each developmental stage (Student's $t$ test, $p<0.05$ ). 


\section{DISCUSSION}

Lethal toxicity, population growth and biological parameter studies were combined to assess the toxicity of the neem oil Bioneem to the cassava green mite $M$. tanajoa, a key cassava pest in Northeastern Brazil and in other tropical countries. Probit analysis confirms the toxicity of neem oil to the cassava green mite; however, the recommended field concentration of this biopesticide to control pest mites only matched the $\mathrm{LC}_{30}$, which indicates that the field rate should be higher in order to efficiently control the cassava green mite.

Organisms exposed to pesticides are known to suffer non-lethal effects (Stark and Banks, 2003; Teodoro et al., 2005; Desneux et al., 2007; Teodoro et al., 2009) that are, therefore, not visible on the mortality bioassays such as lethal toxicity studies. Here, when growth rate and biological parameters were considered as endpoints of nonlethal effects of neem oil the results were corroborative. In our bioassays, mites were exposed to neem oil both by direct contact toxicity and residual activity. The sublethal concentrations of the neem oil reduced the $r_{i}$ of the cassava green mite in a concentration-dependent manner. However, $r_{i}$ values were positive, indicating population increase of $M$. tanajoa up to exposures to the $\mathrm{LC}_{50}$ of the neem oil. Population extinction $\left(\mathrm{N}_{\mathrm{f}}=0\right)$ occurred only after mites were exposed to $\mathrm{LC}_{95}$ and $\mathrm{LC}_{99}$. This is in line with a study by Venzon et al. (2005), which found sublethal effects of the neem pesticide NeemAzal on growth rate of coffee red spider mite Oligonychus ilicis (McGregor) (Acari: Tetranychidae).

The developmental periods of egg, larva, protonymph, deutonymph, and chrysalid stages of $M$. tanajoa were reduced by $\mathrm{LC}_{50}$ of neem oil resulting in a shorter egg-to-adult period. The reduction in the duration of the phases of development of $M$. tanajoa reduces the exposure time of their sensitive immature stages to toxic compounds of the neem oil. Similarly, Gonçalves et al. (2001) found that the duration of immature stages of $M$. tanajoa were reduced by neem extract. In another study, azadirachtin accelerated instar maturation of the elm leaf beetle Xanthogaleruca luteola Müller (Zimmerman et al., 1995). In the present study, duration of oviposition and postoviposition (but not preoviposition) periods of $M$. tanajoa were also reduced by the $\mathrm{LC}_{50}$ of neem oil. The fecundity of $M$. tanajoa was affected by the $\mathrm{LC}_{50}$ of neem oil causing a reduction in the number of eggs laid (daily and total) compared to control. The fecundity of $M$. tanajoa was negatively impacted by an egg reduction of over $80 \%$ in comparison to control. The exposure to azadirachtin and neem oil-based pesticides at different concentrations also reduced the fecundity of two-spotted spider mite Tetranychus urticae Koch (Martínez-Villar et al., 2005; Gauraha and Singh, 2011).

Although there are phytoseiid predatory mites associated with populations of the cassava green mite, these natural enemies alone are unlikely to prevent $M$. tanajoa outbreaks, especially in regions like Northeastern Brazil in the dry season, during which population peaks of the pest are at its highest (Onzo et al., 2005; Moraes and Flechtmann, 2008; Rêgo et al.,2012; 2013). In this scenario, the use of relatively selective pesticides like neem may help to achieve an efficient control of the cassava green mite while not suppress natural enemies' populations. In a parallel study, we show that the recommended field concentration of the neem oil Bioneem was unable to kill the generalist predatory mite Proprioseiopsis neotropicus (Acari: Phytoseiidae), indicating that this biopesticide is selective to this natural enemy. Several other studies point to a relatively selectivity of neem-derived pesticides towards predatory mites (Cote et al., 2002; Venzon et al., 2005; Khater, 2012).

\section{CONCLUSIONS}

Our approach allowed a comprehensive evaluation of neem oil toxicity to the cassava green mite $M$. tanajoa by integrating lethal with non-lethal studies. Neem oil showed lethal as well as sublethal toxicity on growth rate and biological parameters of the cassava green mite and it could be used as an excellent alternative for the management of this pest.

\section{ACKNOWLEDGEMENTS}

We thank the National Council for Scientific and Technological Development (CNPq) and the Federal Agency for Support and Evaluation of Graduate Education (CAPES) for funding.

\section{LITERATURE CITED}

Alzoubi, S., and S. Cobanoglu. 2008. Toxicity of some pesticides against Tetranychus urticae and its predatory mites under laboratory conditions. American-Eurasian Journal of Agricultural and Environmental Sciences 3:30-37.

Caboni, P., G. Sarais, A. Angioni, A.J. Garcia, F. Lai, F. Dedola, and P. Cabras. 2006. Residues and persistence of neem formulations on strawberry after field treatment. Journal of Agricultural and Food Chemistry 54:10026-10032.

Cordeiro, E.M.G., A.S. Corrêa, M. Venzon, and R.N.C. Guedes. 2010. Insecticide survival and behavioral avoidance in the lacewings Chrysoperla externa and Ceraeochrysa cubana. Chemosphere 81:1352-1357.

Cote, K.W., E.E. Lewis, and P.B. Schultz. 2002. Compatibility of acaricide residues with Phytoseiulus persimilis and their effect on Tetranychus urticae. HortScience 37:906-909.

Desneux, N., A. Decourtye, and J.M. Delpuech. 2007. The sublethal effects of pesticides on beneficial arthropods. Annual Review of Entomology 52:81-106.

Gauraha, R., and R.N. Singh. 2011. Effect of bio-pesticides on various stages of spider mite (Tetranychus urticae Koch). Research Journal of Agricultural Sciences 2:301-303.

Gonçalves, M.E.C., R.O. Barros, e J.B. Torres. 2001. Efeito de extratos vegetais sobre estágios imaturos e fêmeas adultas de Mononychellus tanajoa (Bondar) (Acari: Tetranychidae). Neotropical Entomology 30:305-309. 
Isman, M.B. 2006. Botanical insecticides, deterrents, and repellents in modern agriculture and an increasingly regulated world. Annual Review of Entomology 51:45-66.

Khater, H.F. 2012. Prospects of botanical biopesticides in insect pest management. Pharmacologia 3(12):641-656.

Kim, M., C. Sim, D. Shin, E. Suh, and K. Cho. 2006. Residual and sublethal effects of fenpyroximate and pyridaben on the instantaneous rate of increase of Tetranychus urticae. Crop Protection 25:542-548.

Marcic, D. 2007. Sublethal effects of spirodiclofen on life history and life-table parameters of two-spotted spider mite (Tetranychus urticae). Experimental and Applied Acarology 42:121-129.

Martínez-Villar, E., F.J. Sáenz-de-Cabezón, F. Moreno-Grijalba, V. Marco, and I. Pérez-Moreno. 2005. Effects of azadirachtin on the two-spotted spider mite, Tetranychus urticae (Acari: Tetranychidae). Experimental and Applied Acarology 35:215222.

Moraes, G.J., e C.H.W. Flechtmann. 2008. Manual de acarologia: Acarologia básica e ácaros de plantas cultivadas no Brasil. 308 p. Holos, Ribeirão Preto, Brazil.

Mordue (Luntz), A.J., E.D. Morgan, and A.J. Nisbet. 2005. Azadirachtin, a natural product in insect control. p. 117-135. In Gilbert, L.I., K. Iatrou, and S.S. Gill (eds.) Comprehensive molecular insect science. Elsevier, Oxford, UK.

Onzo, A., R. Hanna, M.W. Sabelis, and J.S. Yaninek. 2005. Temporal and spatial dynamics of an exotic predatory mite and its herbivorous mite prey on cassava in Benin, West Africa. Environmental Entomology 34:866-874.

Rêgo, A.S., A.G.S. Maciel, E.C. Costa, E.A. Silva, and A.V. Teodoro. 2012. Comparative biology and growth rate of the mites Mononychellus tanajoa and Euseius ho (Acari) on cassava. Revista Colombiana de Entomologia 38:243-246.

Rêgo, A.S., A.V. Teodoro, A.G.S. Maciel, and R.A. Sarmento. 2013. Relative contribution of biotic and abiotic factors to the population density of the cassava green mite, Mononychellus tanajoa (Acari: Tetranychidae). Experimental and Applied Acarology doi:10.1007/s10493-013-9667-9.

Robertson, J.L., Russell, R.M., H.K. Preisler, and N.E. Savin. 2007. Pesticide bioassays with arthropods. CRC, Boca Raton, Florida, USA.

SAS Institute. 2002. SAS/STAT User's guide. Version 8. SAS Institute, Cary, North Carolina, USA.
Stark, J.D., and J.E. Banks. 2003. Population-level effects of pesticides and other toxicants on arthropods. Annual Review of Entomology 48:505-519.

Stark, J.D., and T.M. Rangus. 1994. Lethal and sublethal effects of the neem insecticide formulation, margosan-o, on the pea aphid. Pesticide Science 41:155-160.

Stark, J.D., and J.F. Walter. 1995. Neem oil and neem oil components affect the efficacy of commercial neem insectides. Journal of Agricultural and Food Chemistry 43:507-512.

StatSoft Inc. 1984-2004. Statistics for Windows (Software-system for data-analyses). Version 7.0. StatSoft Inc., Tulsa, Oklahoma, USA.

Suja, G., S.K. John, J. Sreekumar, and T. Srinivas. 2010. Shortduration cassava genotypes for crop diversification in the humid tropics: growth dynamics, biomass, yield and quality. Journal of the Science of Food and Agriculture 90:188-198.

Systat Software Inc. 2008. SigmaPlot for Windows (development and testing procedures). Version 11.0. Triestram \& Partner GmbH, Bochum, Germany.

Teodoro A.V., M.A.M. Fadini, W.P. Lemos, R.N.C. Guedes, and A. Pallini. 2005. Lethal and sub-lethal selectivity of fenbuntatin oxide and sulfur to the predator Iphiseiodes zuluagai (Acari: Tetranychidae), in Brazilian coffee plantations. Experimental and Applied Acarology 36:61-70.

Teodoro A.V., A. Pallini, and C. Oliveira. 2009. Sub-lethal effects of fenbutatin oxide on prey location by the predatory mite Iphiseiodes zuluagai (Acari: Phytoseiidae). Experimental and Applied Acarology 47:293-299.

Ullah, M.S., D. Moriya, M. Kongchuensin, P. Konvipasruang, and T. Gotoh. 2011. Comparative toxicity of acaricides to Tetranychus merganser Boudreaux and Tetranychus kanzawai Kishida (Acari: Tetranychidae). International Journal of Acarology 37:535-543.

Venzon, M., M.C. Rosado, M.A.M. Fadini, A.I. Ciociola, and A. Pallini. 2005. The potential of NeemAzal for the control of coffee leaf pests. Crop Protection 24:213-219.

Walthall, W.K., and J.D. Stark. 1997. Comparison of two population-level ecotoxicological endpoints: the intrinsic $\left(\mathrm{r}_{\mathrm{m}}\right)$ and instantaneous $\left(\mathrm{r}_{\mathrm{i}}\right)$ rates of increase. Environmental Toxicology and Chemistry 16:1068-1073.

Zimmerman, R.J., D.C. Sclar, T. Randolph, and W.S. Cranshaw. 1995. Toxicity of neem-derived insecticides to various life stages of the elm leaf beetle. Journal of Arboriculture 21:181-186. 